\title{
Water Level Fluctuations and Air Temperatures Affect Common Reed Habitus and Productivity in an Intermittent Wetland Ecosystem
}

\author{
Alenka Gaberščik*, Mateja Grašič $\mathbb{D}$, Dragan Abram and Igor Zelnik $\mathbb{D}$ \\ Department of Biology, Biotechnical Faculty, University of Ljubljana, Večna pot 111, SI-1000 Ljubljana, Slovenia; \\ mateja.grasic@bf.uni-lj.si (M.G.); dragan.abram@gmail.com (D.A.); igor.zelnik@bf.uni-lj.si (I.Z.) \\ * Correspondence: alenka.gaberscik@bf.uni-lj.si; Tel.: +386-1-320-33-43
}

Received: 30 August 2020; Accepted: 6 October 2020; Published: 10 October 2020

\begin{abstract}
Lake Cerknica is an intermittent wetland ecosystem with extreme water level fluctuations. It hosts extensive reed stands that have colonized different habitat types. Two different stands were compared: a lake stand not directly influenced by the intermittent River Stržen and a riparian stand near River Stržen. Reed productivity (growth and assimilate allocation) was monitored for these reed stand types over 13 years (2007-2019), and this measurement was compared to monthly water levels and air temperatures. Reeds from the lake reed stand were significantly shorter with a lower shoot density, overall biomass production, and ratio of flowering plants. A correlation analysis revealed stronger and more numerous significant correlations between environmental and reed productivity parameters for the lake reed stand compared to the riparian reed stand. The variabilities of the growth and assimilate allocation parameters in the lake reed stand were both mostly explained by the combined water levels for June and July, which explained $47 \%$ and $52 \%$ of the variability, respectively. The most influential temperatures were in May, which explained $29 \%$ and $19 \%$ of the variability of growth and assimilate allocation parameters, respectively. For the riparian reed stand, water levels and temperatures out of the vegetation season appeared more important. Therefore, habitats with permanent water are more suitable for reeds than those with fluctuating water. However, fluctuating water conditions are expected to become more common due to climate change.
\end{abstract}

Keywords: Phragmites australis; water level fluctuations; temperature; morphometric parameters; biomass allocation

\section{Introduction}

Water level fluctuations directly affect ecosystems through their effects on the aquatic organisms, and they indirectly affect them by changing the physical and chemical conditions [1] that control different levels of the community structure [2]. The common reed (Phragmites australis (Cav.) Trin. and Steud) is a highly productive and cosmopolitan perennial helophyte that colonizes different wetland habitats [3]. It forms dense monospecific stands and is the dominant plant species in many ecosystems $[4,5]$. It shows high intraspecific diversity and phenotypic plasticity that enable its acclimation to adverse environmental conditions [6]. This is why the common reed is widely distributed across a variety of habitats [7].

One of the most important factors that significantly alters the habitat conditions of the common reed is the water level $[1,5,8,9]$. This defines the availability of water and nutrients [10], as well as the presence of oxygen in the root zone [11], and thus influences the structure of the reed stands. This is a collective result of different processes that include photosynthesis, respiration, mortality, and assimilate translocation between shoots and below-ground plant organs [12]. Li et al. [13] showed that water 
depth is a key driver in the shaping of common reed biomass production, plant height, basal diameter, and density. The common reed can tolerate water depths of up to $2 \mathrm{~m}$. A decrease in water level positively affects the plants, which reflects in an increase in their assimilation area [14,15]. High water levels might also prevent rhizosphere self-oxidation via radial oxygen loss and might thus result in hypoxia [16]. Like many other helophytes, the common reed is only moderately tolerant to oxygen shortage $[17,18]$. High water levels are especially unfavorable at the beginning of the growing season because they slow down the early development of the plants [5,19].

Lake Cerknica is an intermittent wetland ecosystem that has extensive reed stands [20]. These reed stands cover the shallower parts of the lake area, the riparian zones of the lake tributaries, and the riparian zone of the intermittent River Stržen, which meanders across the exposed lake-bed. These habitats offer different conditions for reed stands in terms of the duration and extent of the lake floodwaters [21]. In addition to the spatial differences of these floodwaters, reed stands are also greatly influenced by water level fluctuations throughout the year. This pattern depends on the temporal and spatial distributions of precipitation over the watershed, which extends over $575 \mathrm{~km}^{2}$ [22]. These results in water level fluctuations that are more pronounced in the lake habitat in comparison to the riparian habitat, which is permanently conditioned by water from the watercourse. These water level fluctuations do not always harmonize with the developmental cycles of the plants, including the common reed [23]. Any deviations in the normal rhythm will affect the habitus and productivity of these reeds [5]. The best conditions for the common reed are during 'normal' floods, when the water reaches the highest level in spring and then gradually decreases until summer, when the lake usually dries out. However, with autumnal rainfalls, the water level can increase again and then slowly decrease during the winter period [22]. Along with the water levels, the temperatures also have an important influence because they can significantly affect the beginning of the growing season and its length [24].

There have been many studies, which included the measurements of reed productivity parameters in relation to water level fluctuations. However, the majority of them have only presented short-term results, e.g., [13-15]. In the present study, we analyzed datasets of reed productivity parameters from the monitoring of two reed stand types at Lake Cerknica over 13 years (2007-2019)—namely the lake reed stand and the riparian reed stand. The productivity parameters were divided into two groups - the growth and assimilate allocation parameters-and were related to the environmental conditions in terms of the monthly water levels and air temperatures. These two parameters are also expected to fluctuate due to global climate change, and, therefore, this study not only provides an insight into the conditions of reed stands at Lake Cerknica but also shows the trends that will be relevant for other reed stands in other water bodies considering the likely future climate changes. We hypothesized that the most critical environmental conditions for these reeds are those in spring, when the reeds emerge from the rhizomes, and those in the autumn, as these might affect the length of the growing season. We also hypothesized that these critical periods would be of different importance relative to the two reed stand types.

\section{Materials and Methods}

\subsection{Site Description}

Lake Cerknica is located at the bottom of the Cerkniško polje depression. Polje is a karst feature that is characterized by an intermittent river that originates at one margin of the polje and sinks at the other side (Figure 1). At the Cerkniško polje, the river is called River Stržen, and the polje is its floodplain. Lake Cerknica is a Ramsar and Natura 2000 site, and it is part of the Notranjska Regional Park. The majority of the water that enters the lake is of karst origin, which reaches the lake from underground. In spring and usually in late autumn, the water surface of Lake Cerknica reaches an altitude of $550 \mathrm{~m}$ a.s.l., with flooding over an area of $26 \mathrm{~km}^{2}$. The flooding phase of the lake lasts over a relatively long period, usually about 9 months of each year; thus, the floodplain area is dry for 
2-3 months of each year. The pattern of water level fluctuations varies significantly over different years [22]. The extent and duration of these floodwaters result in a variety of habitats that change over time $[5,21,25]$. Different plant communities show clear zonal distributions that depend on the extent, duration, and frequency of these floodwaters [20].

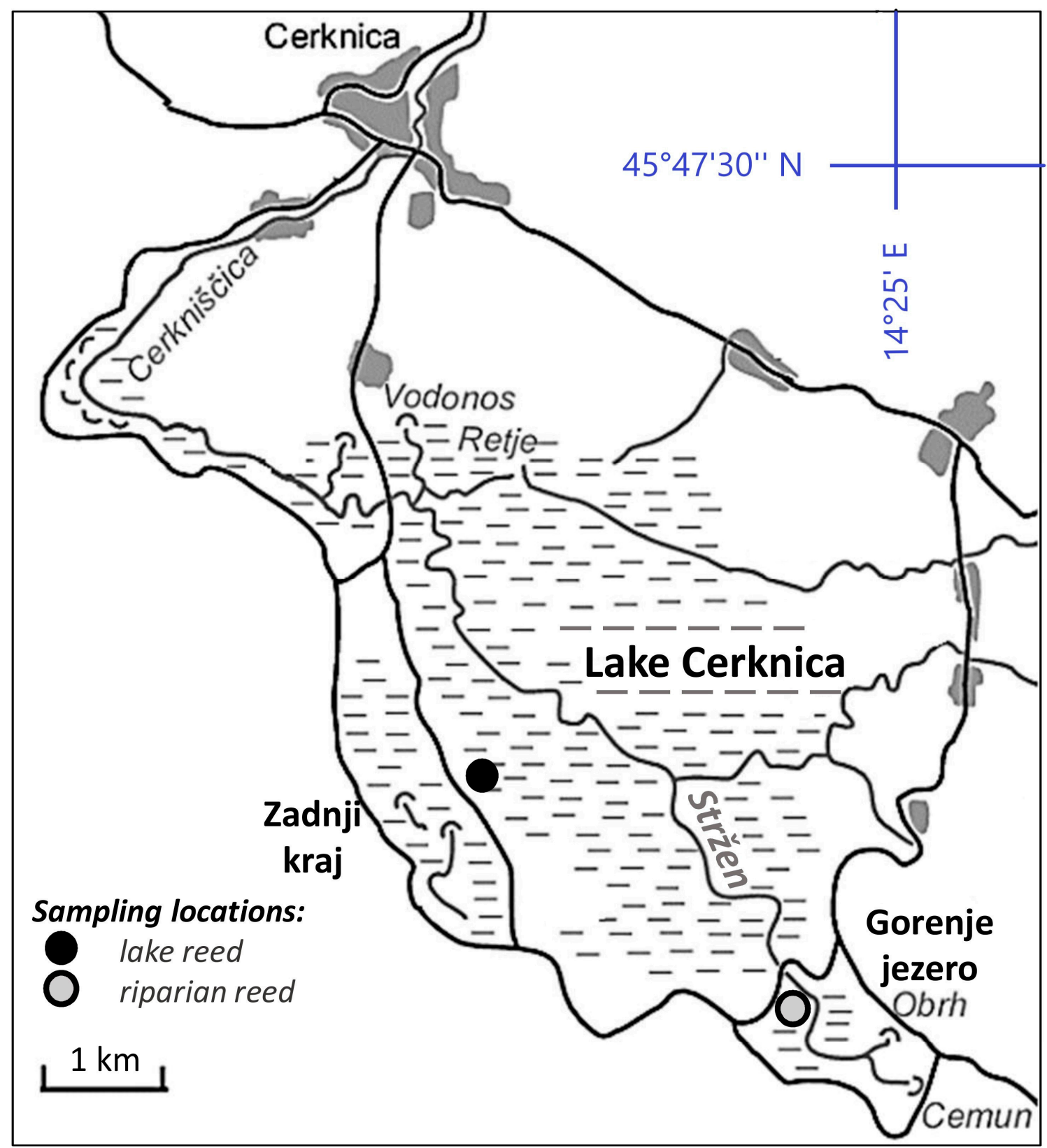

Figure 1. Map of the study area showing the two sampling locations.

Reed productivity parameters were measured here for two different reed stand types: (a) in a lake reed stand at Zadnji Kraj $\left(45^{\circ} 44^{\prime} 27^{\prime \prime} \mathrm{N} ; 14^{\circ} 22^{\prime} 13^{\prime \prime} \mathrm{E}\right)$, which experiences extreme water level fluctuations (from $\sim 2 \mathrm{~m}$ high to completely dry), and (b) in a riparian reed stand in the vicinity of the intermittent River Stržen at Gorenje Jezero $\left(45^{\circ} 43^{\prime} 40^{\prime \prime} \mathrm{N} ; 14^{\circ} 24^{\prime} 17^{\prime \prime} \mathrm{E}\right)$ at the edge of the polje, where the water levels are usually $<0.5 \mathrm{~m}$ and where the soil water-table remains high even during dry periods (Figure 1). 


\subsection{Productivity Parameters}

The harvesting of the above-ground parts of the reed plants from 2007 to 2019 was performed during the fruiting phase at the end of the growing season, in September, following the work of Květ et al. [26] and Cronk and Fennessy [27]. Five $0.5 \times 0.5 \mathrm{~m}$ plots were harvested from each location at each sampling. In addition to the plant above-ground biomass, the following parameters were determined: shoot density, flowering shoots, internodes and leaves per plant, shoot height, and shoot basal diameter.

\subsection{Environmental Parameters}

The water level data were obtained from the Stržen-Gorenje Jezero monitoring station of the Slovenian Environment Agency (Figure 2) and the air temperatures from the nearest weather station (Postojna), as available from http://www.meteo.si/ (Figure 3).

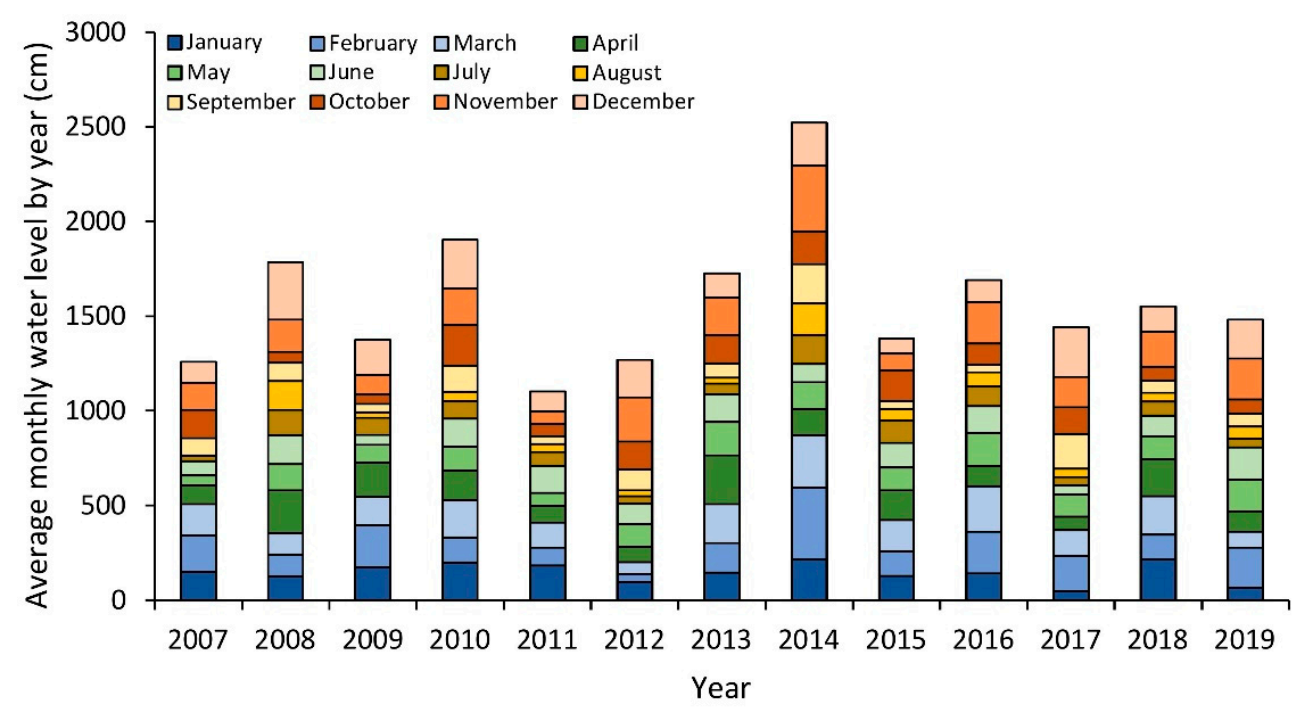

Figure 2. Average monthly water levels at the Stržen-Gorenje Jezero monitoring station (obtained from the Slovenian Environment Agency).

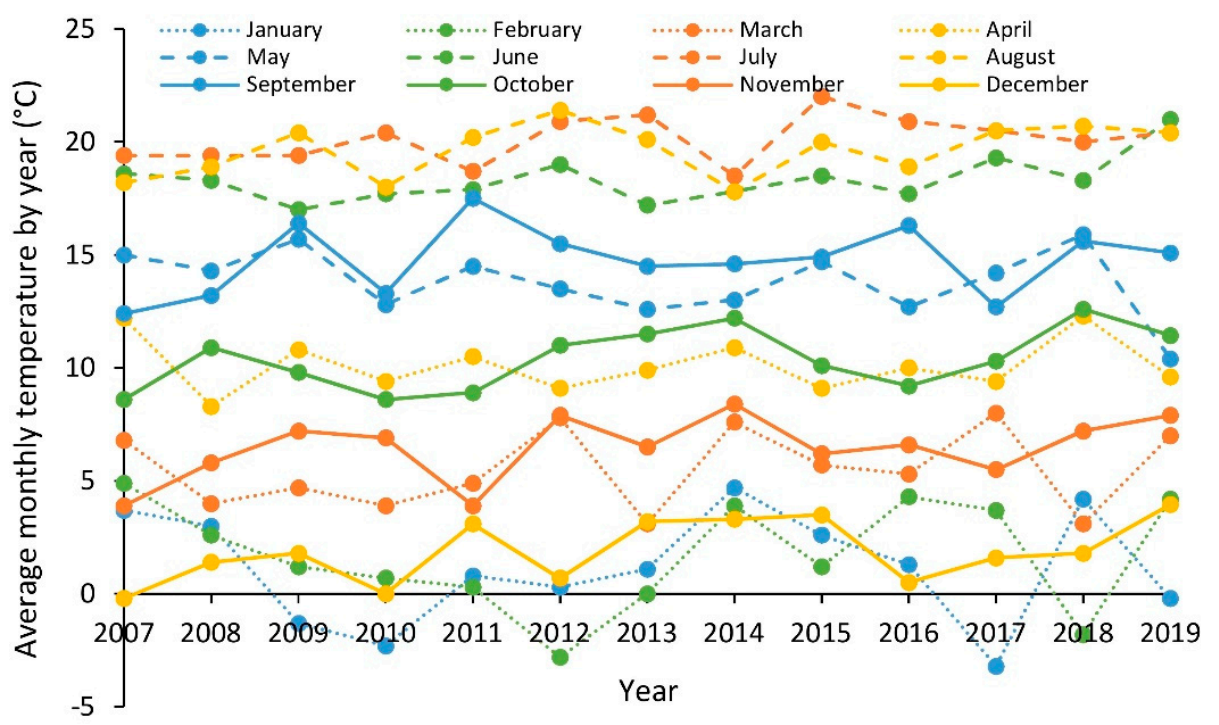

Figure 3. Average monthly air temperatures at the Postojna weather station (obtained from http://www.meteo.si/). 


\subsection{Statistical Analysis}

Using the SPSS statistic software, version 22.0 (IBM Corp., Armonk, NY, USA), statistically significant differences between the lake and riparian reed stand productivities were evaluated using Mann-Whitney non-parametric tests, and the relationships between different productivity and environmental parameters were calculated using Spearman's correlation analysis.

To examine the impact of water level and air temperature on reed plant productivity, we considered the data from the corresponding year (January to August) and from the end of the growing season from the year before (September to December), which might have affected the accumulation of reserves in the reed rhizomes.

A detrended correspondence analysis was used for the exploratory data analysis using the Canoco for Windows 4.5 program package (Microcomputer Power: Ithaca, NY, USA). Due to the obtained gradient lengths ( $<3$ standard deviations) [28], a redundancy analysis (RDA) was used to determine whether the variations in the productivity parameters were related to monthly water levels and/or air temperatures. Productivity was determined as two groups: the growth parameters (i.e., shoot density, internodes, leaves per plant, shoot height, and stem basal diameter) and the assimilate allocation parameters (i.e., flowering shoots, biomass of leaves, stems, and flowers). The significance of the effects of the variables was determined using Monte Carlo tests with 999 permutations. The forward selection of the explanatory variables was used to avoid collinearity. All of the variables used in the analysis were standardized.

\section{Results}

Common reeds from the lake and riparian reed stands significantly differed for the productivity parameters (Table 1). Reeds from the lake reed stand were significantly shorter, with significantly lower shoot density, overall biomass production, and ratio of flowering plants. The habitus of single plants was similar regarding stem basal diameter and the number of internodes and leaves but not regarding height and biomass per plant (lake reed stand: $8.8 \mathrm{~g}$ per plant; riparian reed stand: $12.0 \mathrm{~g}$ per plant). The samples from the lake reed stand generally showed a higher variability in the measured parameters in comparison to the riparian reed stand samples.

Table 1. Productivity parameters for the common reed from the lake (Zadnji Kraj) and riparian (Gorenje Jezero) reed stands from 2007 to 2019.

\begin{tabular}{|c|c|c|c|c|}
\hline \multirow{2}{*}{ Parameter } & \multirow{2}{*}{ Units } & \multicolumn{2}{|c|}{ Reed Stand } & \multirow[t]{2}{*}{$p$} \\
\hline & & Lake & Riparian & \\
\hline & & Mean \pm S.D. & Mean \pm S.D. & \\
\hline Height & $\mathrm{cm}$ & $148.05 \pm 30.59$ & $183.27 \pm 26.49$ & $\leq 0.001$ \\
\hline Basal diameter & $\mathrm{mm}$ & $5.25 \pm 1.00$ & $5.15 \pm 0.78$ & ns \\
\hline Internodes/plant & $\mathrm{n}$ & $16.33 \pm 1.70$ & $16.01 \pm 1.68$ & ns \\
\hline Leaves/plant & $\mathrm{n}$ & $9.46 \pm 3.20$ & $9.89 \pm 2.40$ & ns \\
\hline Plants & $\mathrm{n} / \mathrm{m}^{2}$ & $50.40 \pm 20.89$ & $64.86 \pm 26.36$ & $\leq 0.001$ \\
\hline Leaf dry mass & $\mathrm{g} / \mathrm{m}^{2}$ & $105.28 \pm 46.77$ & $159.26 \pm 72.37$ & $\leq 0.001$ \\
\hline Rest dry mass & $\mathrm{g} / \mathrm{m}^{2}$ & $338.67 \pm 192.44$ & $619.62 \pm 270.72$ & $\leq 0.001$ \\
\hline Flowering & $\mathrm{n} / \mathrm{m}^{2}$ & $22.98 \pm 15.23$ & $36.36 \pm 14.32$ & $\leq 0.001$ \\
\hline Flowering & $\%$ & $47.59 \pm 26.63$ & $58.71 \pm 18.09$ & $\leq 0.05$ \\
\hline
\end{tabular}

ns: not significant (Mann-Whitney non-parametric tests).

A correlation analysis revealed much stronger and more numerous significant correlations between the environmental and reed productivity parameters for the lake reed stand than for the riparian reed stand. For the lake stand, the reed productivity was mostly affected by the water levels at the end of the previous growing season, in October and November of the previous year, and the water levels at the beginning of the current season, in May and June. Almost all of these relations were negative (Table 2). 
May and June were also the most important months regarding the air temperatures. However, the effects here were generally positive.

Table 2. Spearman's correlations between growth and biomass allocation parameters, as well as water levels and air temperatures, for the common reed plants from the lake reed stand (Zadnji Kraj).

\begin{tabular}{|c|c|c|c|c|c|c|c|c|c|c|c|c|}
\hline \multirow{2}{*}{ Parameter } & \multicolumn{4}{|c|}{ Previous Year } & \multicolumn{8}{|c|}{ Current Year } \\
\hline & Sept. & Oct. & Nov. & Dec. & Jan. & Feb. & Mar. & Apr. & May. & Jun. & Jul. & Aug. \\
\hline \multicolumn{13}{|l|}{ Water Level } \\
\hline Height & 0.13 & -0.30 & -0.29 & 0.15 & 0.10 & 0.01 & 0.07 & 0.09 & -0.47 & -0.28 & 0.07 & -0.17 \\
\hline Basal diameter & -0.16 & -0.70 & -0.38 & 0.06 & -0.16 & 0.06 & -0.29 & 0.05 & -0.40 & -0.34 & -0.35 & -0.48 \\
\hline Internodes/plant & 0.15 & -0.28 & -0.26 & 0.08 & -0.15 & 0.30 & -0.08 & -0.08 & -0.33 & -0.21 & -0.22 & -0.18 \\
\hline Leaves/plant & -0.28 & -0.27 & -0.37 & -0.40 & -0.42 & -0.33 & -0.47 & -0.02 & 0.20 & 0.58 & -0.31 & 0.09 \\
\hline Plants $/ \mathrm{m}^{2}$ & 0.03 & -0.22 & -0.02 & 0.27 & 0.25 & 0.11 & 0.06 & 0.17 & -0.03 & -0.19 & 0.00 & -0.32 \\
\hline Leaf dry matter/m² & -0.16 & -0.55 & -0.48 & 0.01 & -0.00 & -0.29 & -0.18 & 0.02 & -0.22 & -0.06 & -0.51 & -0.61 \\
\hline Rest dry matter/m² & 0.00 & -0.54 & -0.38 & 0.23 & 0.23 & -0.04 & -0.01 & 0.08 & -0.48 & -0.47 & -0.12 & -0.51 \\
\hline Flowering $\left(\mathrm{n} / \mathrm{m}^{2}\right)$ & 0.17 & -0.19 & -0.21 & 0.21 & 0.22 & 0.09 & 0.07 & 0.08 & -0.50 & -0.44 & 0.19 & -0.21 \\
\hline Flowering (\%) & 0.15 & -0.01 & -0.17 & -0.02 & 0.03 & -0.06 & 0.11 & 0.01 & -0.41 & -0.28 & 0.16 & -0.00 \\
\hline \multicolumn{13}{|l|}{ Air Temperature } \\
\hline Height & 0.00 & 0.05 & 0.03 & 0.22 & -0.03 & 0.22 & -0.13 & 0.00 & 0.56 & 0.00 & -0.02 & -0.20 \\
\hline Basal diameter & 0.25 & 0.13 & -0.09 & 0.09 & -0.30 & 0.13 & 0.08 & -0.02 & 0.33 & 0.11 & -0.02 & 0.11 \\
\hline Internodes/plant & 0.07 & 0.52 & 0.18 & 0.46 & 0.06 & 0.51 & 0.18 & 0.21 & 0.36 & 0.33 & 0.04 & 0.01 \\
\hline Leaves/plant & 0.32 & -0.13 & -0.01 & -0.14 & -0.14 & 0.07 & -0.05 & -0.40 & -0.38 & 0.45 & 0.13 & 0.03 \\
\hline Plants $/ \mathrm{m}^{2}$ & -0.03 & 0.05 & -0.08 & 0.03 & -0.13 & -0.27 & -0.09 & 0.16 & 0.03 & -0.46 & -0.08 & 0.05 \\
\hline Leaf dry matter $/ \mathrm{m}^{2}$ & 0.41 & -0.21 & -0.05 & -0.05 & -0.29 & -0.29 & -0.23 & -0.03 & 0.06 & -0.09 & 0.11 & 0.11 \\
\hline Rest dry matter/m² & 0.16 & -0.02 & -0.14 & 0.20 & -0.17 & -0.16 & -0.05 & 0.09 & 0.49 & -0.22 & -0.07 & -0.01 \\
\hline Flowering $\left(\mathrm{n} / \mathrm{m}^{2}\right)$ & -0.16 & 0.03 & -0.11 & 0.20 & 0.05 & 0.16 & -0.02 & 0.09 & 0.61 & -0.19 & -0.21 & -0.22 \\
\hline Flowering (\%) & -0.06 & -0.03 & 0.02 & 0.18 & 0.17 & 0.27 & -0.02 & -0.07 & 0.52 & 0.11 & -0.03 & -0.28 \\
\hline
\end{tabular}

Shaded fields contain statistically significant coefficients (light grey: $0.01 \leq p \leq 0.05$; dark grey: $p \leq 0.01$.

In the riparian reed stand, the parameters most positively correlated to the water level were plant basal diameter and the height of the plants, while basal diameter was negatively correlated to air temperatures (Table 3). The correlation analysis showed the importance of the winter months, especially December and January, when water level negatively correlated with the number of internodes.

Table 3. Spearman's correlations between growth and biomass allocation parameters, as well as water levels and air temperatures, for the common reed plants from the riparian reed stand (Gorenje Jezero).

\begin{tabular}{|c|c|c|c|c|c|c|c|c|c|c|c|c|}
\hline \multirow{2}{*}{ Parameter } & \multicolumn{4}{|c|}{ Previous Year } & \multicolumn{8}{|c|}{ Current Year } \\
\hline & Sept. & Oct. & Nov. & Dec. & Jan. & Feb. & Mar. & Apr. & May. & Jun. & Jul. & Aug. \\
\hline \multicolumn{13}{|l|}{ Water Level } \\
\hline Height & -0.04 & 0.16 & -0.12 & -0.30 & -0.21 & 0.20 & 0.04 & 0.02 & 0.17 & 0.14 & 0.36 & 0.46 \\
\hline Basal diameter & 0.32 & -0.11 & -0.13 & 0.26 & 0.31 & 0.02 & 0.07 & 0.45 & -0.10 & 0.22 & 0.44 & 0.06 \\
\hline Internodes/plant & -0.23 & 0.02 & -0.00 & -0.35 & -0.34 & 0.36 & 0.04 & 0.03 & 0.35 & 0.01 & -0.11 & 0.20 \\
\hline Leaves/plant & -0.25 & -0.03 & -0.06 & -0.30 & -0.27 & 0.18 & 0.08 & 0.10 & 0.24 & -0.19 & -0.19 & -0.09 \\
\hline Plants $/ \mathrm{m}^{2}$ & -0.07 & -0.26 & -0.19 & 0.09 & 0.13 & -0.06 & -0.12 & -0.10 & -0.19 & 0.03 & -0.12 & -0.14 \\
\hline Leaf dry matter/m² & -0.02 & -0.12 & -0.32 & -0.03 & 0.10 & 0.05 & 0.01 & 0.07 & -0.13 & -0.06 & 0.04 & -0.09 \\
\hline Rest dry matter/m² & 0.13 & -0.02 & -0.16 & 0.07 & 0.22 & 0.13 & 0.11 & 0.11 & -0.06 & 0.11 & 0.30 & 0.14 \\
\hline Flowering $\left(\mathrm{n} / \mathrm{m}^{2}\right)$ & -0.01 & -0.05 & -0.07 & -0.06 & 0.06 & 0.13 & 0.07 & -0.02 & 0.09 & 0.07 & 0.12 & 0.16 \\
\hline Flowering (\%) & 0.05 & 0.30 & 0.11 & -0.22 & -0.09 & 0.12 & 0.13 & -0.03 & 0.25 & 0.05 & 0.22 & 0.35 \\
\hline \multicolumn{13}{|l|}{ Air Temperature } \\
\hline Height & -0.10 & 0.22 & 0.02 & 0.33 & 0.23 & 0.53 & 0.17 & -0.20 & -0.05 & 0.19 & 0.08 & -0.32 \\
\hline Basal diameter & -0.31 & 0.11 & 0.10 & -0.03 & 0.16 & 0.15 & -0.37 & -0.02 & 0.20 & -0.36 & -0.34 & -0.56 \\
\hline Internodes/plant & -0.02 & 0.16 & -0.10 & -0.03 & 0.10 & 0.40 & 0.13 & 0.03 & -0.23 & 0.21 & 0.10 & 0.08 \\
\hline Leaves/plant & -0.05 & -0.15 & -0.31 & -0.21 & 0.02 & 0.05 & -0.05 & 0.03 & -0.08 & -0.03 & 0.18 & 0.25 \\
\hline Plants $/ \mathrm{m}^{2}$ & 0.15 & -0.05 & 0.05 & -0.01 & -0.18 & -0.01 & -0.01 & 0.06 & 0.02 & -0.00 & -0.21 & -0.08 \\
\hline Leaf dry matter $/ \mathrm{m}^{2}$ & -0.13 & -0.14 & -0.19 & -0.05 & 0.05 & 0.13 & -0.14 & 0.11 & 0.17 & -0.14 & -0.22 & -0.14 \\
\hline Rest dry matter $/ \mathrm{m}^{2}$ & -0.12 & 0.15 & 0.10 & 0.19 & 0.14 & 0.27 & -0.09 & 0.07 & 0.08 & -0.16 & -0.23 & -0.43 \\
\hline Flowering $\left(\mathrm{n} / \mathrm{m}^{2}\right)$ & 0.14 & 0.30 & 0.17 & 0.35 & 0.10 & 0.20 & 0.15 & 0.00 & -0.13 & 0.07 & -0.00 & -0.24 \\
\hline Flowering (\%) & -0.01 & 0.29 & 0.09 & 0.36 & 0.34 & 0.21 & 0.24 & -0.08 & -0.14 & 0.18 & 0.17 & -0.14 \\
\hline
\end{tabular}

Shaded fields contain statistically significant coefficients (light grey: $0.01 \leq p \leq 0.05$; dark grey: $p \leq 0.01$ ). 
A redundancy analysis was performed separately for the growth and assimilate allocation parameters, with different results shown. For the lake reed stand, the water levels in spring and summer appeared to be the most important parameter (Table 4 and Figures 4 and 5). The variability of the growth and assimilate allocation parameters was mostly explained by the combined water levels for June and July, which explained $47 \%$ of the variability for growth and $52 \%$ of the variability for assimilate allocation. The water levels in the other months were less important for the lake reed stand, although when combined, they explained an additional $18 \%$ and $24 \%$ of the variability of the growth and assimilate allocation parameters, respectively. High water levels in July and August negatively affected the number of leaves and internodes for the lake reed stand. The RDA plots revealed large differences across the study years (Figures 4 and 5).

For the air temperatures for the lake reed stand, the most influential month was May, which explained $29 \%$ of the variability of the growth parameters and $19 \%$ of the variability of the assimilate allocation parameters (Table 4). Air temperatures explained a total of $86 \%$ of the variability of the growth and a total of $76 \%$ of the variability of the assimilate allocation.

Table 4. Redundancy analysis for the significant explained variance for the growth and assimilate allocation parameters for the lake reed stand (Zadnji Kraj), as defined by the monthly water levels and air temperatures.

\begin{tabular}{|c|c|c|c|c|}
\hline Parameter Class & Monthly Parameter & Month & Explained Variance (\%) & $p$ \\
\hline \multirow{16}{*}{ Growth } & \multirow{5}{*}{ Water level } & June & 22 & 0.001 \\
\hline & & July & 25 & 0.001 \\
\hline & & August & 8 & 0.002 \\
\hline & & April & 5 & 0.003 \\
\hline & & February & 5 & 0.003 \\
\hline & \multirow{11}{*}{ Air temperature } & May & 29 & 0.001 \\
\hline & & August & 12 & 0.001 \\
\hline & & July & 10 & 0.001 \\
\hline & & January & 8 & 0.001 \\
\hline & & March & 5 & $<0.01$ \\
\hline & & December & 5 & $<0.01$ \\
\hline & & September & 4 & $<0.01$ \\
\hline & & October & 4 & $<0.01$ \\
\hline & & April & 3 & $<0.01$ \\
\hline & & July & 3 & $<0.01$ \\
\hline & & February & 3 & $<0.01$ \\
\hline \multirow{15}{*}{ Assimilate allocation } & \multirow{6}{*}{ Water level } & July & 23 & 0.001 \\
\hline & & June & 29 & 0.001 \\
\hline & & April & 10 & 0.001 \\
\hline & & May & 6 & 0.004 \\
\hline & & October & 4 & $<0.01$ \\
\hline & & September & 4 & $<0.01$ \\
\hline & \multirow{9}{*}{ Air temperature } & May & 19 & 0.001 \\
\hline & & December & 13 & 0.001 \\
\hline & & October & 8 & 0.001 \\
\hline & & January & 7 & 0.002 \\
\hline & & March & 7 & 0.002 \\
\hline & & April & 5 & 0.001 \\
\hline & & February & 5 & 0.001 \\
\hline & & September & 6 & $<0.01$ \\
\hline & & August & 6 & $<0.01$ \\
\hline
\end{tabular}




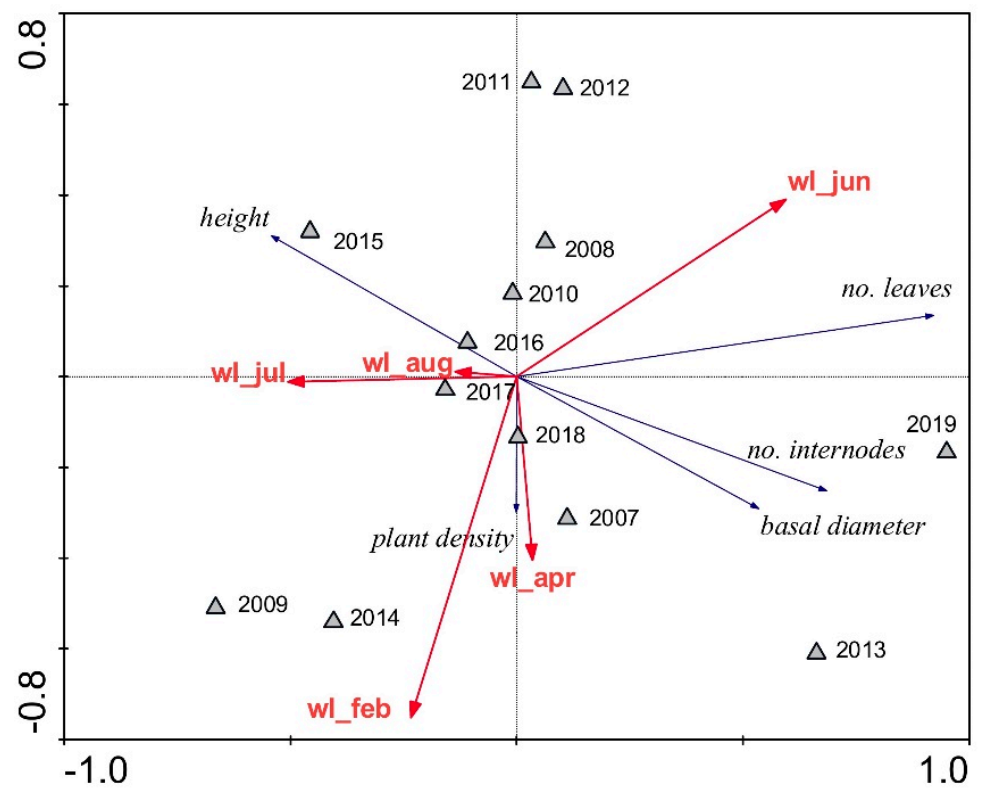

Figure 4. Redundancy analysis plot showing the strengths of the associations between monthly water levels and growth parameters of the common reed from the lake stand (Zadnji Kraj). Triangles: different years; wl: water level; no.: number.

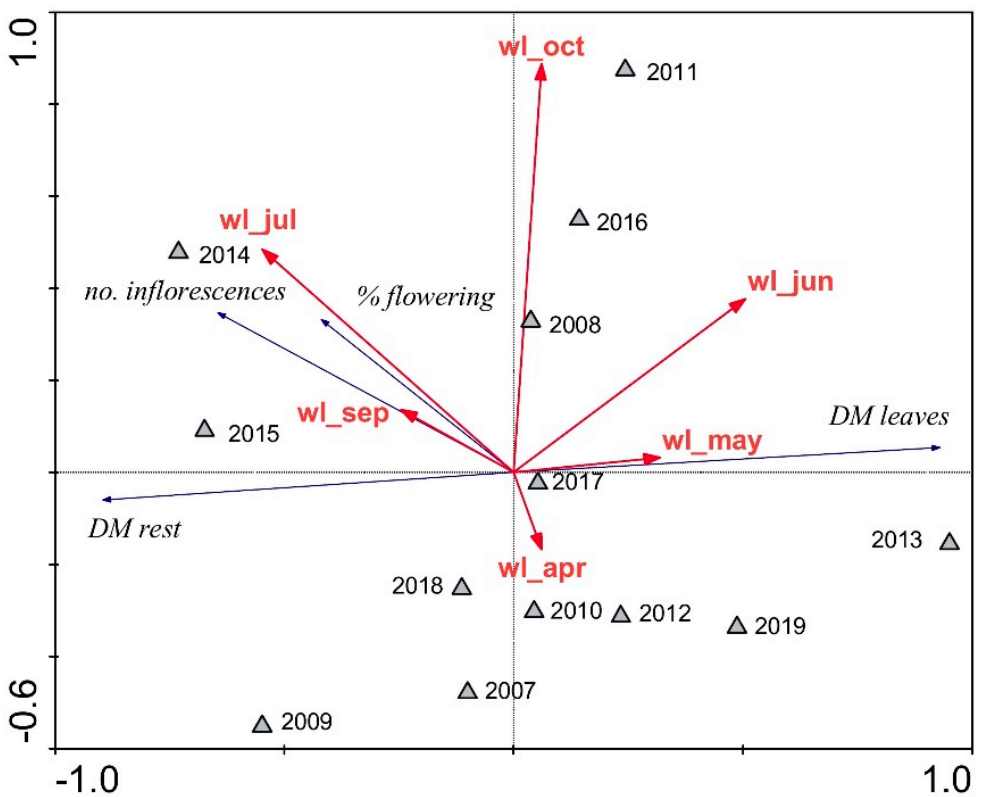

Figure 5. Redundancy analysis plot showing the strengths of the associations between monthly water levels and assimilate allocation parameters of the common reed from the lake stand (Zadnji Kraj). Triangles: different years; DM: dry mass; wl: water level; no.: number.

For the riparian reed stand, the water levels out of the vegetation season appeared to be the most important (Table 5 and Figures 6 and 7). The variability of the growth parameters was mostly explained by the combined water levels in February and December, which explained $34 \%$ of the variability. Meanwhile, the importance of the water levels in the other months was much lower, as only an additional $21 \%$ of sample variability was explained. The variability of the assimilate allocation parameters was mostly explained by the combined water levels in January and November, which explained $41 \%$ of the variability. Again, the importance of water levels in the other months was 
lower, with an additional $24 \%$ of the sample variability explained. The RDA plot again revealed large differences here across the study years.

Table 5. Redundancy analysis for the significant explained variance for the growth and assimilate allocation parameters for the riparian reed stand (Gorenje Jezero), as defined by the monthly water levels and air temperatures.

\begin{tabular}{|c|c|c|c|c|}
\hline Parameter Class & Monthly Parameter & Month & Explained Variance (\%) & $p$ \\
\hline \multirow{9}{*}{ Growth } & \multirow{5}{*}{ Water level } & February & 19 & 0.001 \\
\hline & & December & 15 & 0.001 \\
\hline & & September & 9 & 0.002 \\
\hline & & October & 5 & 0.002 \\
\hline & & January & 7 & 0.001 \\
\hline & \multirow{4}{*}{ Air temperature } & October & 15 & 0.001 \\
\hline & & June & 11 & 0.002 \\
\hline & & January & 8 & $<0.01$ \\
\hline & & July & 8 & $<0.01$ \\
\hline \multirow{9}{*}{$\begin{array}{l}\text { Assimilate } \\
\text { allocation }\end{array}$} & \multirow{5}{*}{ Water level } & January & 22 & 0.001 \\
\hline & & November & 19 & 0.001 \\
\hline & & July & 9 & 0.001 \\
\hline & & October & 9 & 0.007 \\
\hline & & August & 6 & 0.006 \\
\hline & \multirow{4}{*}{ Air temperature } & July & 17 & 0.001 \\
\hline & & February & 11 & 0.004 \\
\hline & & October & 9 & 0.007 \\
\hline & & April & 6 & 0.004 \\
\hline
\end{tabular}

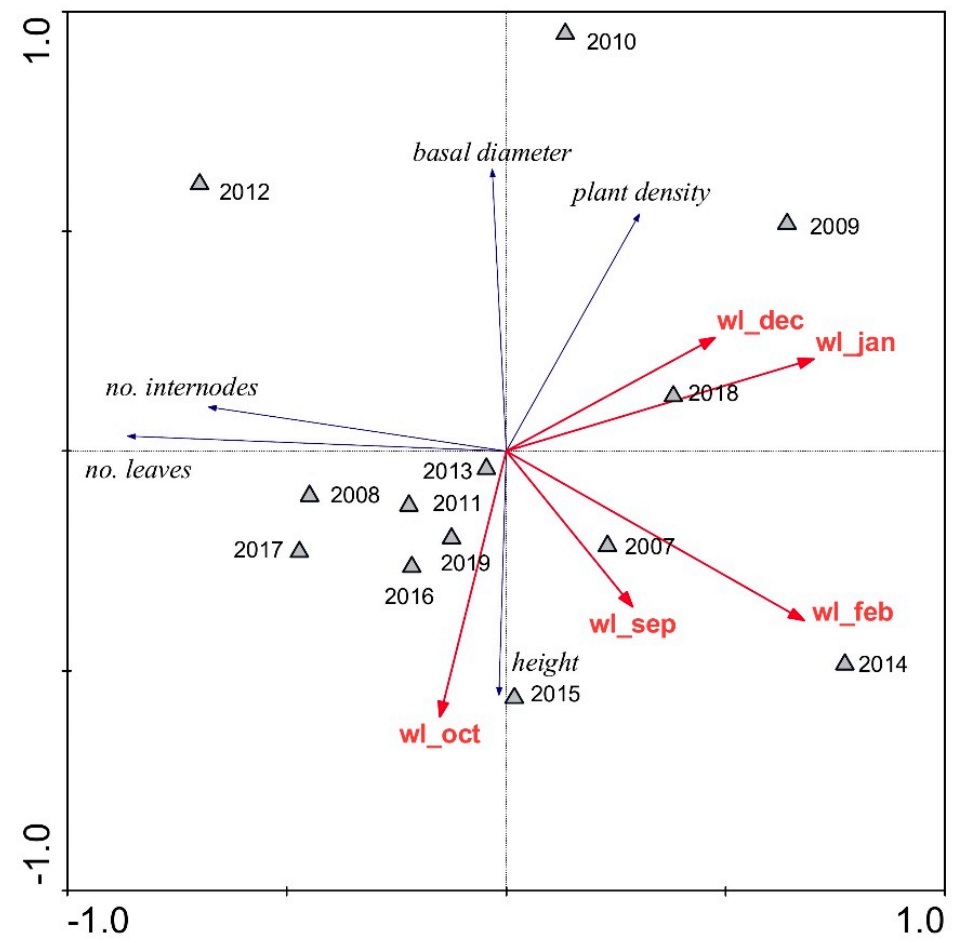

Figure 6. Redundancy analysis plot showing the strengths of the associations between monthly water levels and growth parameters of the common reed from the riparian stand (Gorenje Jezero). Triangles: different years; wl: water level; no.: number. 


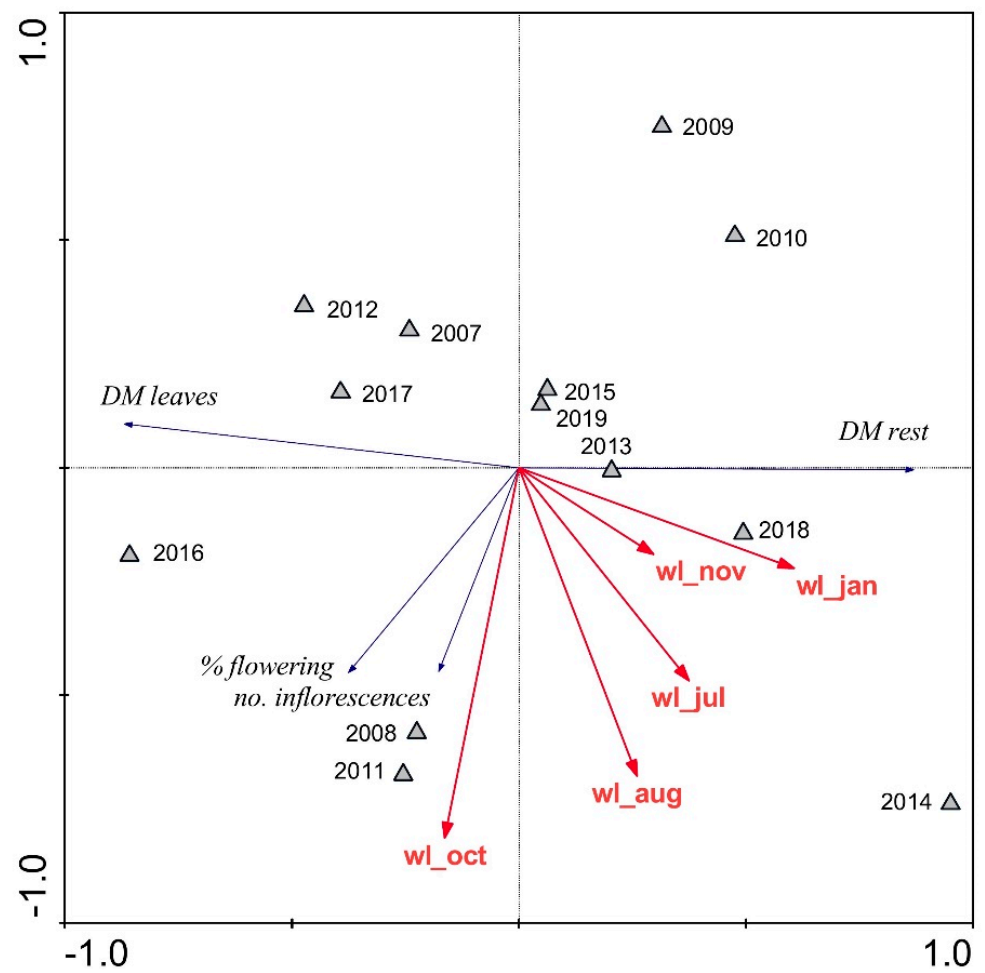

Figure 7. Redundancy analysis plot showing the strengths of the associations between monthly water levels and assimilate allocation parameters of the common reed from the riparian stand (Gorenje Jezero). Triangles: different years; DM: dry mass; wl: water level; no.: number.

For the air temperatures for the riparian reed stand, the most influential months were October and June, which explained $26 \%$ of the variability of the growth parameters, and July and February, which explained $28 \%$ of the variability of the assimilate allocation parameters (Table 5). Altogether, the air temperatures explained a total of $42 \%$ of the variability of the growth parameters and a total of $43 \%$ of the variability of the assimilate allocation parameters.

We also examined whether the reed productivity in the previous year affected the productivity parameters in the following (current) year. Here, the RDA revealed that the numbers of leaves, the number of internodes, the biomass of the leaves, and the biomass of the other parts in the previous year explained $8 \%, 4 \%, 4 \%$, and $4 \%$, respectively, of the productivity parameters in the following year. Therefore, these parameters combined explained $20 \%$ of the variability of the productivity parameters in the following year.

\section{Discussion}

The common reed is successful in habitats with stable or regular hydrology [29]. The higher variability in the measured parameters for samples from the lake reed stand in comparison to those from the riparian reed stand was a consequence of extreme water level fluctuations. For the lake location here, this could range from completely dry soil to $2 \mathrm{~m}$ depth of water, while the nearby River Stržen in the riparian reed stand maintains permanent high soil water table and floods up to $0.5 \mathrm{~m}$. Hayball and Pearce [30] reported that in deep water, the common reed developed lower numbers of shoots, while a decrease in the water level increased the plant density and leaf numbers, which positively affected the leaf area index and consequently affected the productivity [15]. A high density of reed culms causes self-shading, which decreases the flowering rate and increases the leaf to stem mass ratio [29]. On the other hand, culm height and density significantly contribute to the competitive success of the common reed in terms of the shading out of other plant competitors in the habitat [31]. 
Plants that develop during moderate constant water levels grow faster than plants growing under fluctuating water levels $[32,33]$. This is also supported by the above-ground biomass measurements in the present study. The common reed is especially sensitive to rapid and extreme water level changes [34]. Extreme fluctuations affect reed fitness, partly due to the disturbed oxygenation of the rhizosphere [35] and possibly also due to negative effects on active mycorrhiza [36,37]. Such extreme changes are characteristic of the lake reed stand at Zadnji Kraj. In contrast, the more gradual changes that occur in the riparian reed stand at Gorenje Jezero appear to be less detrimental. In water fluctuation systems, the timing of the changes in water levels is also very important. For the lake reed stand at Zadnji Kraj, the variability of the growth and assimilate allocation parameters was explained by water levels in June and July $(p<0.001)$, which was the time of the vegetative development of plants, whereas temperatures seemed to be most important in May $(p<0.001)$. For the riparian reed stand at Gorenje Jezero, most of the variability of the growth and assimilate allocation parameters was explained by water levels out of the vegetation season and by temperatures at the end of the vegetation season, which may be related to the filling of reserves [5]. For the lake reed stand, there was positive correlation between leaf numbers and water levels in June $(0.58 ; p<0.01)$, and there were negative correlations with water levels in July $(-0.31 ; p<0.01)$ and from December to March $(p<0.05)$. On the other hand, no such significant correlations were found for the riparian reed stand, except for the negative correlation seen for December $(-0.30 ; p<0.05)$. Plant growth depends on the levels of available carbohydrates, which are strongly affected by environmental conditions [3]. A correlation analysis showed that in the lake reed stand, the plant height was negatively affected by the water levels in October of the previous year and in May and June of the current year, but it was positively related with air temperatures in May. In the riparian reed stand, the plant height was related to the water levels in December $(-0.30 ; p$ $<0.05)$, July $(0.36 ; p<0.01)$, and August $(0.46 ; p<0.01)$. Autumnal rainfall can shorten the vegetation period and thus interrupt the filling of the reserves in the rhizomes, while high waters in late spring can prevent the development of reeds $[5,32,38]$. Previous studies have shown positive relationships between stem height and shoot density, which reflect productivity during the vegetation season [39]. However, no such correlation was obtained in the present study. The growth parameter that was most strongly correlated to the water level was basal diameter. For the lake reed stand, a strong negative correlation was obtained throughout the whole period of the vegetative development of reed, while for the riparian stand, this relation was strongly positive in April and June. This was possibly the consequence of the differences in maximal water levels between the two locations that might be unfavorable for lake but not for riparian stands. Thinner culms, which occurred in the years with deeper water, are more vulnerable to physical disturbances such as strong water movements and winds $[40,41]$.

Irregular and strong water movements are usually the consequence of extreme water level fluctuations, like waves or currents, and may negatively affect the competitiveness of the common reed [29]. Water movement represents a physical force that can break reed culms and prevents the passive and humidity-induced aeration of the rhizome system at higher water levels, which also occurs via dead stems $[16,42]$. In water fluctuating systems, reed stands are frequently subjected to prolonged dry periods [21]. The common reed can withstand longer periods of water shortage through a reduction in leaf area and by an increased water-use efficiency [43]. Drought events are very common for the lake reed stand at Zadnji Kraj during the summer periods, with a positive correlation seen here between water levels and the numbers of leaves in June and July.

The negative effect on reed productivity may also be due to extreme temperatures, which may significantly increase the evapotranspiration rate in summer and may negatively affect reed rhizomes in winter. For example, Bodensteiner and Gabriel [44] attributed the reduction in reed stand area in the Upper Winnebago Pool Lakes in Wisconsin (USA) to the combined effects of extreme water levels and low temperatures in winter. We also obtained positive correlations with temperatures and some of the measured productivity parameters in the winter months at both locations. 
In addition to differences in environmental factors like water levels, total radiation, and temperature, the fitness of plants during the previous season might also have a strong impact on plant height [3]. The present study showed little effect of the reed productivity parameters in the previous season, as these parameters explained only $20 \%$ of the variability of the productivity parameters in the current year.

This study showed that water depth represents the most important factor in common reed life. However, water depth is also an important predictor for the spread of common reed, which expands where the water levels are decreasing [45]. Water levels at the two locations affected different common reed parameters in different ways. In spite of that, water depth regulation may present a strong management tool [46], especially in human-made and human-managed aquatic systems. The increased extent of water level fluctuation in many aquatic systems may also be the consequence of different hydro-melioration measures in the landscape and thus the reduced capacity of the landscape to store water [47], as well as due to altered precipitation regimes due to global climate change. Renaturation measures to increase landscape water capacity may benefit every reed stand. Vital reed stands may increase the resilience of the landscape because by producing high biomass quantities, they provide various ecosystem services. They positively affect the local climate, purify water, present a source of biomass and a reservoir for water, and serve as a habitat and refuge for a variety of species $[25,33,48-51]$.

\section{Conclusions}

This study has shown that habitats with the permanent presence of water are more suitable habitats for the common reed in comparison to those with fluctuating water levels. This presents a problem in the light of global climate change, since water level fluctuations in different water bodies are expected to become more frequent. A favorable water regime in a landscape positively affects common reed production and its ecosystems services. Thus, measures to increase landscape water capacity, including assuring favorable conditions for reed stands, are needed to mitigate future extremes.

Author Contributions: Conceptualization, A.G.; methodology, A.G. and D.A.; validation, A.G., M.G., and I.Z.; formal analysis, A.G., M.G., and D.A.; investigation, D.A.; writing-original draft preparation, A.G.; writing-review and editing, A.G., M.G., and I.Z.; visualization, A.G. and M.G.; supervision, A.G.; project administration, A.G.; funding acquisition, A.G. All authors have read and agreed to the published version of the manuscript.

Funding: This study was funded by the Slovenian Research Agency, grant numbers P1-0212 and 39096.

Acknowledgments: The authors are grateful to Christopher Berrie for his revision of the English language.

Conflicts of Interest: The authors declare no conflict of interest. The funders had no role in the design of the study; in the collection, analyses, or interpretation of data; in the writing of the manuscript; or in the decision to publish the results.

\section{References}

1. Yi, Y.; Xie, H.; Yang, Y.; Zhou, Y.; Yang, Z. Suitable habitat mathematical model of common reed (Phragmites australis) in shallow lakes with coupling cellular automaton and modified logistic function. Ecol. Model. 2020, 419, 108938. [CrossRef]

2. Hill, N.M.; Keddy, P.A.; Wisheu, I.C. A Hydrological model for predicting the effects of dams on the shoreline vegetation of lakes and reservoirs. Environ. Manag. 1998, 22, 723-736. [CrossRef] [PubMed]

3. Clevering, O.A.; Brix, H.; Lukavská, J. Geographic variation in growth responses in Phragmites australis. Aquat. Bot. 2001, 69, 89-108. [CrossRef]

4. Hocking, P.J.; Finlayson, C.M.; Chick, A.J. The biology of Australian weeds. 12. Phragmites australis (Cav.) Trin. ex Stuedel. J. Aust. Institute Agric. Sci. 1983, 40, 123-132.

5. Dolinar, N.; Regvar, M.; Abram, D.; Gaberščik, A. Water-level fluctuations as a driver of Phragmites australis primary productivity, litter decomposition, and fungal root colonisation in an intermittent wetland. Hydrobiology 2015, 774, 69-80. [CrossRef] 
6. Eller, F.; Skálová, H.; Caplan, J.S.; Bhattarai, G.P.; Burger, M.K.; Cronin, J.T.; Guo, W.-Y.; Guo, X.; Hazelton, E.L.G.; Kettenring, K.M.; et al. Cosmopolitan species as models for ecophysiological responses to global change: The common reed Phragmites australis. Front. Plant. Sci. 2017, 8, 1833. [CrossRef]

7. Clevering, O.A.; Lissner, J. Taxonomy, chromosome numbers, clonal diversity and population dynamics of Phragmites australis. Aquat. Bot. 1999, 64, 185-208. [CrossRef]

8. Engloner, A.I.; Papp, M. Vertical differences in Phragmites australis culm anatomy along a water depth gradient. Aquat. Bot. 2006, 85, 137-146. [CrossRef]

9. Tóth, V.R. Reed stands during different water level periods: Physico-chemical properties of the sediment and growth of Phragmites australis of Lake Balaton. Hydrobiology 2016, 778, 193-207. [CrossRef]

10. Grašič, M.; Dobravc, M.; Golob, A.; Vogel-Mikuš, K.; Gaberščik, A. Water shortage reduces silicon uptake in barley leaves. Agric. Water Manag. 2019, 217, 47-56. [CrossRef]

11. Armstrong, W.; Justin, S.; Beckett, P.; Lythe, S. Root adaptation to soil waterlogging. Aquat. Bot. 1991, 39, 57-73. [CrossRef]

12. Asaeda, T.; Karunaratne, S. Dynamic modeling of the growth of Phragmites australis: Model description. Aquat. Bot. 2000, 67, 301-318. [CrossRef]

13. Li, C.; Ye, X.; Wu, M.; Shao, X. Effects of water depth and coexistence on growth characteristics of Phragmites australis and Typha domingensis. Soc. Wetl. Sci. Bull. 2015, 13, 609-615.

14. Squires, L.; Van Der Valk, A.G. Water-depth tolerances of the dominant emergent macrophytes of the Delta Marsh, Manitoba. Can. J. Bot. 1992, 70, 1860-1867. [CrossRef]

15. Tóth, V.R.; Szabó, K. Morphometric structural analysis of Phragmites australis stands in Lake Balaton. Ann. de Limnol. -Int. J. Limnol. 2012, 48, 241-251. [CrossRef]

16. Armstrong, J.; Armstrong, W. Light-enhanced convective throughflow increases oxygenation in rhizomes and rhizosphere of Phragmites australis (Cav.). Trin. ex Steud. New Phytol. 1990, 114, 121-128. [CrossRef]

17. Brändle, R.; Crawford, R.M.M. Rhizome anoxia tolerance and habitat specialization in wetland plants. In Plant Life in Aquatic and Amphibious Habitats; Crawford, R.M.M., Ed.; Blackwell Scientific Publications: Oxford, UK, 1987; pp. 397-410.

18. Armstrong, J.; Afreen-Zobayed, F.; Blyth, S.; Armstrong, W. Phragmites australis: Effects of shoot submergence on seedling growth and survival and radial oxygen loss from roots. Aquat. Bot. 1999, 64, 275-289. [CrossRef]

19. Schmieder, K.; Dienst, M.; Ostendorp, W.; Jöhnk, K. Effects of water level variations on the dynamics of the reed belts of Lake Constance. Ecohydrol. Hydrobiol. 2004, 4, 229-239.

20. Martinčič, A.; Leskovar, I. Vegetation. In The Vanishing Lake-Monograph on Lake Cerknica; Gaberščik, A., Ed.; Slovenian ecological society: Ljubljana, Slovenia, 2003; pp. 80-96.

21. Dolinar, N.; Šraj, N.; Gaberščik, A. Water regime changes and the function of an intermittent wetland. In Water and Nutrient Management in Natural and Constructed Wetlands; Vymazal, J., Ed.; Springer: Dordrecht, The Netherlands, 2011; pp. 251-262.

22. Kranjc, A. Hydrological characteristics. In The Vanishing Lake-Monograph on Lake Cerknica; Gaberščik, A., Ed.; Slovenian Ecological Society: Ljubljana, Slovenia, 2003; pp. 26-38.

23. Gaberščik, A.; Urbanc-Bercic, O.; Kržič, N.; Kosi, G.; Brancelj, A. The intermittent Lake Cerknica: Various faces of the same ecosystem. Lakes Reserv. Res. Manag. 2003, 8, 159-168. [CrossRef]

24. Eller, F.; Lambertini, C.; Nguyen, L.X.; Achenbach, L.; Brix, H. Interactive effects of elevated temperature and $\mathrm{CO} 2$ on two phylogeographically distinct clones of common reed (Phragmites australis). AoB PLANTS 2013, 5, pls051. [CrossRef]

25. Dolinar, N.; Rudolf, M.; Šraj, N.; Gaberščik, A. Environmental changes affect ecosystem services of the intermittent Lake Cerknica. Ecol. Complex. 2010, 7, 403-409. [CrossRef]

26. Květ, J.; Westlake, D.F.; Dykyjova, D.; Marshall, E.J.P.; Ondok, J. Primary production in wetlands. In The Production Ecology of Wetlands; Westlake, D.F., Květ, J., Szczepansky, A., Eds.; Cambridge University Press: Cambridge, UK, 1999; pp. 78-168.

27. Cronk, J.K.; Fennessy, M.S. Wetland Plants: Biology and Ecology, 1st ed.; CRC Press: Boca Raton, FL, USA, 2001.

28. Ter Braak, C.J.F.; Šmilauer, P. CANOCO Reference Manual and CanoDraw for Windows User's Guide: Software for Canonical Community Ordination (Version 4.5); Microcomputer Power: Ithaca, NY, USA, 2002. 
29. Packer, J.G.; Meyerson, L.A.; Skálová, H.; Pyšek, P.; Kueffer, C. Biological flora of the British isles: Phragmites australis. J. Ecol. 2017, 105, 1123-1162. [CrossRef]

30. Hayball, N.; Pearce, M. Influences of simulated grazing and water-depth on the growth of juvenile Bolboschoenus caldwellii, Phragmites australis and Schoenoplectus validus plants. Aquat. Bot. 2004, 78, 233-242. [CrossRef]

31. Onimaru, K.; Yabe, K. Comparisons of nutrient recovery and specific leaf area variation between Carex lasiocarpa var. occultans and Carex thunbergii var. appendiculata with reference to nutrient conditions and shading by Phragmites australis. Ecol. Res. 1996, 11, 139-147. [CrossRef]

32. Vretare, V.; Weisner, S.E.B.; Strand, J.A.; Granéli, W. Phenotypic plasticity in Phragmites australis as a functional response to water depth. Aquat. Bot. 2001, 69, 127-145. [CrossRef]

33. Thevs, N.; Zerbe, S.; Gahlert, F.; Mijit, M.; Succow, M. Productivity of reed (Phragmites australis Trin. ex Steud.) in continental-arid NW China in relation to soil, groundwater, and land-use. J. Appl. Bot. Food Qual. 2007, 81, 62-68.

34. Haslam, S.M. The performance of Phragmites communis Trin. in relation to temperature. Ann. Bot. 1975, 39, 883-888. [CrossRef]

35. White, S.D.; Ganf, G.G. A comparison of the morphology, gas space anatomy and potential for internal aeration in phragmites australis under variable and static water regimes. Aquat. Bot. 2002, 73, 115-127. [CrossRef]

36. Dolinar, N.; Gaberščik, A. Mycorrhizal colonization and growth of Phragmites australis in an intermittent wetland. Aquat. Bot. 2010, 93, 93-98. [CrossRef]

37. Dolinar, N.; Šraj, N.; Pongrac, P.; Regvar, M.; Gaberščik, A. The presence of mycorrhiza in different habitats of an intermittent aquatic ecosystem. In Water and Nutrient Management in Natural and Constructed Wetlands; Vymazal, J., Ed.; Springer: Dordrecht, The Netherlands, 2011; pp. 299-308.

38. Dinka, M.; Ágoston-Szabó, E.; Urbanc-Berčič, O.; Germ, M.; Šraj-Kržič, N.; Gaberščik, A. Reed stand conditions at selected wetlands in Slovenia and Hungary. In Wastewater Treatment, Plant Dynamics and Management in Constructed and Natural Wetlands; Vymazal, J., Ed.; Springer: Dordrecht, The Netherlands, 2008; pp. 1-12.

39. Zhang, W.; Tong, S.; Wang, X.; Liu, B.; Lv, X.; Yang, X. The interaction of water, vegetation and soil in Zhalong wetland, China. J. Food Agric. Environ. 2013, 11, 1287-1294.

40. Engloner, A.I. Structure, growth dynamics and biomass of reed (Phragmites australis)—GA review. Flora 2009, 204, 331-346. [CrossRef]

41. Hong, M.G.; Nam, B.E.; Kim, J.G. Differences in functional traits of leaf blade and culm of common reed in four habitat types. J. Ecol. Environ. 2019, 43, 12. [CrossRef]

42. Afreen, F.; Zobayed, S.; Armstrong, J.; Armstrong, W. Pressure gradients along whole culms and leaf sheaths, and other aspects of humidity-induced gas transport in Phragmites australis. J. Exp. Bot. 2007, 58, 1651-1662. [CrossRef]

43. Pagter, M.; Bragato, C.; Brix, H. Tolerance and physiological responses of Phragmites australis to water deficit. Aquat. Bot. 2005, 81, 285-299. [CrossRef]

44. Bodensteiner, L.R.; Gabriel, A.O. Response of mid-water common reed stands to water level variations and winter conditions in Lake Poygan, Wisconsin, USA. Aquat. Bot. 2003, 76, 49-64. [CrossRef]

45. Tulbure, M.G.; Johnston, C.A. Environmental conditions promoting non-native Phragmites australis expansion in Great Lakes coastal wetlands. Wetlands 2010, 30, 577-587. [CrossRef]

46. Brix, H.; Ye, S.; Laws, E.A.; Sun, D.; Li, G.; Ding, X.; Yuan, H.; Zhao, G.; Wang, J.; Pei, S. Large-scale management of common reed, Phragmites australis, for paper production: A case study from the Liaohe Delta, China. Ecol. Eng. 2014, 73, 760-769. [CrossRef]

47. Gaberščik, A.; Murlis, J. The role of vegetation in the water cycle. Ecohydrol. Hydrobiol. 2011, 11, 175-181. [CrossRef]

48. Kiviat, E. Ecosystem services of Phragmites in North America with emphasis on habitat functions. AoB PLANTS 2013, 5, plt008. [CrossRef]

49. Köbbing, J.F.; Thevs, N.; Zerbe, S. The utilisation of reed (Phragmites australis): A review. Mires Peat 2013, 13. 
50. Gaglio, M.; Lanzoni, M.; Nobili, G.; Viviani, D.; Castaldelli, G.; Fano, E.A. Ecosystem services approach for sustainable governance in a brackish water lagoon used for aquaculture. J. Environ. Plan. Manag. 2019, 62, 1501-1524. [CrossRef]

51. Baibagyssov, A.; Thevs, N.; Nurtazin, S.; Waldhardt, R.; Beckmann, V.; Salmurzauly, R. Biomass resources of Phragmites australis in Kazakhstan: Historical developments, utilization, and prospects. Resources 2020, 9, 74. [CrossRef]

Publisher's Note: MDPI stays neutral with regard to jurisdictional claims in published maps and institutional affiliations.

(C) 2020 by the authors. Licensee MDPI, Basel, Switzerland. This article is an open access article distributed under the terms and conditions of the Creative Commons Attribution (CC BY) license (http://creativecommons.org/licenses/by/4.0/). 